\title{
Wild collection of medicinal and aromatic plants (MAPs) for commercial purposes in Poland - a system's analysis
}

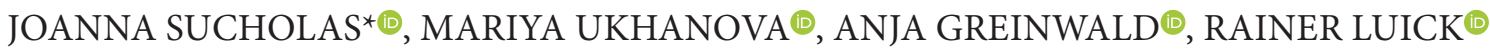

\author{
University of Applied Forest Sciences \\ Schaden Weilerhof \\ 72108 Rottenburg am Neckar \\ Germany \\ *corresponding author: phone +48 797930268; e-mail: j.sucholas@gmail.com
}

\section{Summary}

Introduction: Poland is one of the main exporters of medicinal and aromatic plants (MAPs) in Europe. A substantial part of this plant material is collected in the wild. So far, the system of wild collection (WC) of medicinal plants in Poland, its social and ecological aspects have not been studied comprehensively.

Objective: The aim of the study was to analyse the organisation of WC system in Poland, including legislation, situation of protected species, and socio-ecological dimensions of the MAPs' supply chains.

Methods: Data from environmental agencies $(R D O S)$ about protected MAPs was analysed. Stakeholders engaged in WC were interviewed. National legislation on WC was reviewed.

Results: Although Poland is the second largest exporter of MAPs in Europe, legislation on wild collection in the country is sparse and incoherent. Monitoring does not apply to WC entirely. The structure of WC has a large degree of informality, lacks transparency, and does not take many sustainability criteria into account.

Conclusions: The system needs major adjustments: a) to insure sustainability of WC, b) to accommodate market demands, including plant material quality.

Key words: medicinal and aromatic plants (MAPs), wild collection (WC), legislation, protected species, supply chains, sustainability

Słowa kluczowe: rośliny lecznicze, zbiór ze stanu naturalnego, akty prawne, gatunki chronione, łańcuchy dostaw, stabilność socjo-ekologiczno-ekonomiczna 
A few years ago, collectors could buy a car for money earned from eyebright (Euphrasia rostkoviana L.) trade. Right now it is not as profitable, as it used to be. Herb collector with more than 30 years of experience (Podlaskie, Mai 2018)

I am happy, 'cause I earned 3.000 PLN last summer (ca. 700€) and bought an accordion for my grandson. 70-year-old woman, working as a wild herb collector since childhood (Podlaskie, November 2018)

\section{INTRODUCTION}

Commercial harvest of medicinal plants from nature has decades of tradition in Poland and the existing collection system comes from communist period. This activity used to be popular, so even school-aged young people had often collected medicinal plants as a summer job. Herb collection from nature still provides additional and significant income for people in rural areas. However, currently, mainly older people collect and sell wild herbs, whereas young people are increasingly reluctant to. Aging of collectors and subsequent lack of collection knowledge transmission to the younger generation are among the challenges that Polish herbal market is currently facing. In this paper, we first provide a background while describing general market situation of medicinal and aromatic plants, then, in the major part, we discuss number of problematic issues in the system of medicinal plants collection from natural sites in Poland and ways of solving them.

\section{Background: global and European MAPs market}

The latest available data show the global relevance of the Polish medicinal plants market. In last 10 years, Poland has consistently been found among top fifteen exporters of medicinal and aromatic plants worldwide (tab. 1), according to mean of exported volume in 2010-2019 and confirmed by the maximum and minimum exported volume in the given period.

It is estimated that 50,000 to 70,000 plant species are used for medicinal purposes worldwide, whereas only 3000 of them are traded globally $[1,2]$. Twenty years ago, circa 2000 species could be found on European market $[1,2]$ and probably this number did not decrease. This assessment is based on the analysis of the German market, which is the European leader in imported and exported volumes of medicinal plant material $[1,2]$. However, these numbers relate only to medicinal and aromatic plants (MAPs) defined by Lange [2] as "species which are used medicinally, for cosmetics, as herbal teas, in liqueurs and bitters, as insecticides and fungicides and in domestic cleaning products. Plants associated primarily with food (cereals, vegetables), ornamental use, timber or fuel have been excluded".
Table 1.

Fifteen leading countries in the world in export of medicinal and aromatic plants in 2010-2019

\begin{tabular}{lrrrr}
\hline $\begin{array}{l}\text { Country of } \\
\text { export }\end{array}$ & $\begin{array}{c}\text { Mean } \\
\text { volume } \\
\text { [tons] }\end{array}$ & $\begin{array}{c}\text { Max. } \\
\text { volume } \\
\text { [tons] }\end{array}$ & $\begin{array}{c}\text { Min. } \\
\text { volume } \\
\text { [tons] }\end{array}$ & $\begin{array}{c}\text { Mean value } \\
\text { [1000 US\$] }\end{array}$ \\
\hline China & 187548 & 227038 & 145109 & 959820 \\
\hline India & 81859 & 89250 & 67066 & 243355 \\
\hline Egypt & 60225 & 95271 & 41742 & 101753 \\
\hline Mexico & 25898 & 38410 & 9304 & 48976 \\
\hline Germany & 22207 & 24831 & 19621 & 157484 \\
\hline Morocco & 19749 & 27699 & 14118 & 44210 \\
\hline Poland & $\mathbf{1 6 5 9 8}$ & $\mathbf{1 9 5 8 7}$ & $\mathbf{1 3 9 4 0}$ & $\mathbf{6 6 3 4 5}$ \\
\hline Spain & 15412 & 24321 & 6369 & 63335 \\
\hline USA & 15235 & 17948 & 12794 & 156574 \\
\hline Kazakhstan & 14712 & 29721 & 469 & 7892 \\
\hline Pakistan & 11201 & 18865 & 7896 & 13104 \\
\hline Indonesia & 11125 & 12475 & 8690 & 22921 \\
\hline Bulgaria & 9792 & 10795 & 8101 & 27802 \\
\hline Chile & 9578 & 10914 & 8358 & 34035 \\
\hline Thailand & 8574 & 11823 & 7230 & 11200 \\
\hline
\end{tabular}

Source: own calculations based on UN Comtrade database; used commodity trade code HS 1211, as of October 2020

Recently, another relevant group of plants was recognised as playing a significant role on European market. These species are called "botanicals", namely "plant species that are reported to contain naturally occurring substances of possible impact on human health when present in food" [3]. The group was distinguished to describe the constantly growing market of dietary supplements and enriched food, which contain botanicals. The group consists of 907 species with described active compounds. Annex 1 and Annex 2 to the Compendium of Botanicals [3] provides 380 additional species present on the market, but with no further sufficient information. This fact is an important premise indicating that numbers of traded species might be much higher than previously assumed, even if plant species finally found in medicinal products and dietary supplements are overlapping. Considering the changes in the medicinal plants market, appearance of dietary supplements, which are closer to food products, and often contain herbal plant material, the MAP definition of Lange 
[2] needs to be revised. Nevertheless, in this article, we use the term "MAPs", keeping in mind that the considered species can be present not only in medicines and other primary defined products, but also "food-like" dietary supplements.

In general, the global MAP market is constantly growing (tab. 2). The data shows that since 1990s, total global volume of imported plant material has grown roughly from 440,000 tons to 550,000 tons in 2018. In the same line, the market value of plant material augmented reaching almost 3.5 billion USD in 2018 .

The results of research carried out with companies engaged in trading and manufacturing of natural products and medicines based on plant material indicate that ca. $60-90 \%$ of the traded volume derives from cultivation and not from wild collection (WC) [1]. On the other hand, when looking at the number of traded species only a few hundred are estimated to come from cultivation [1]. This indicates that the vast majority of traded plant species are still collected from natural sites.
Table 2.

Total global import of medicinal and aromatic plants

\begin{tabular}{ccc}
\hline Year & Total volume [tons] & Total value [US\$] \\
\hline 1996 & 440000 & 1300000000 \\
\hline 2008 & 572389 & 1994302274 \\
\hline 2018 & 545528 & 3456610922 \\
\hline
\end{tabular}

Source: Data based on UN Comtrade database; used commodity trade code HS 1211

For 1996 - data of Lange [2], for 2008 and 2018 - authors' own calculations

Usually export volume can give a rough estimation of the volume of MAPs that are sourced in a specific country. Data analysis of the European market show that Poland, with an export rate of more than 5000 tons annually in the last ten years, belongs to the 10 leading countries of MAPs exports in Europe (fig. 1). With more than 20000 tons of export in 2018, Poland was second next to Germany. Figure 2 illustrates in detail numbers of export and import

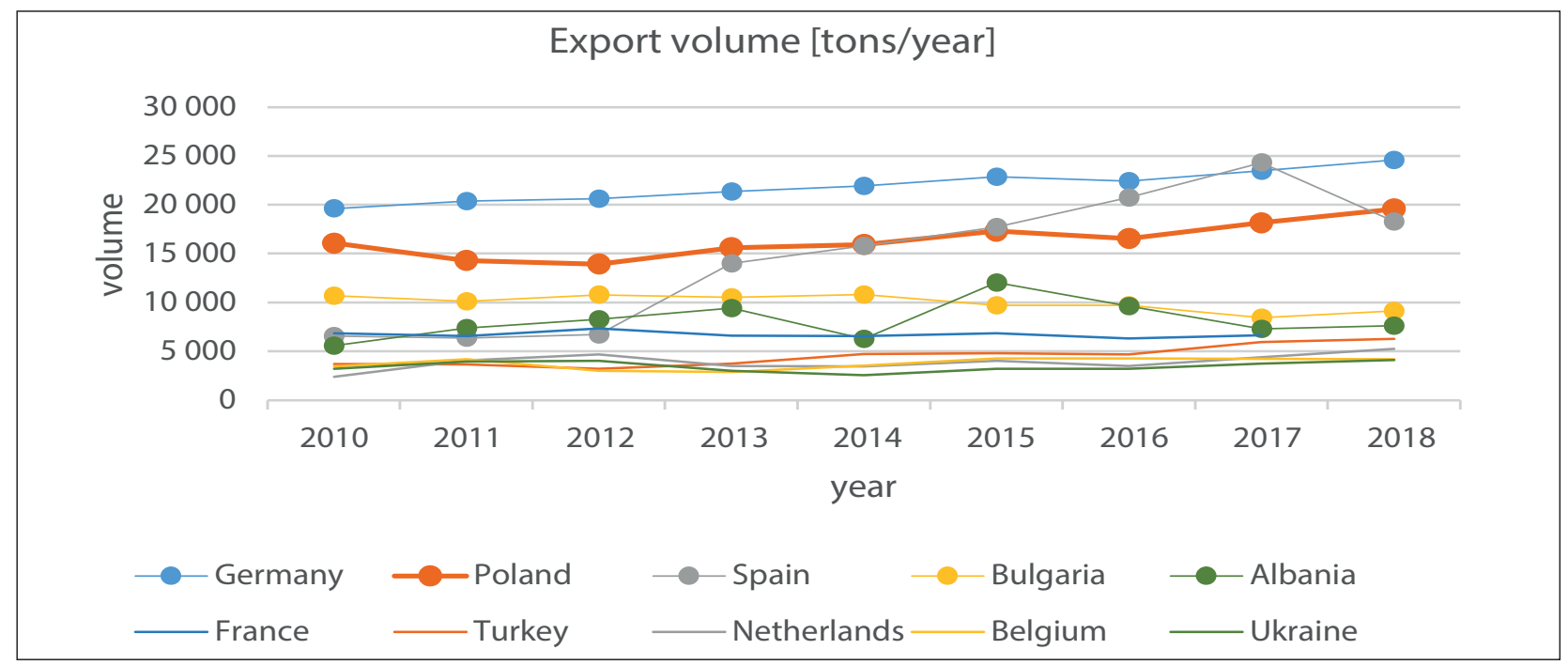

Figure 1.

Annual export volumes of MAPs of the 10 leading European countries in 2010-2018 (source: UN Comtrade database, own calculation)

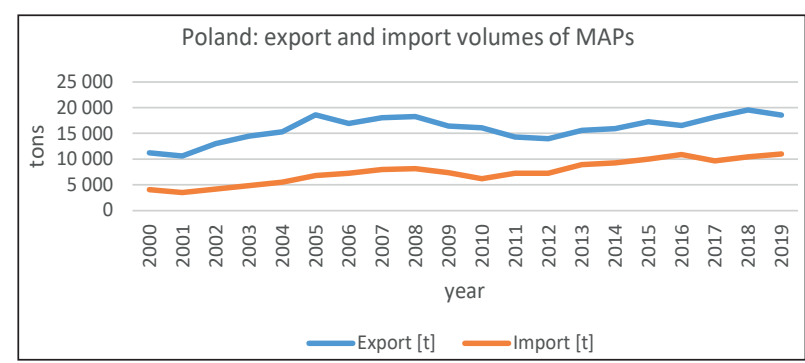

Figure 2.

Annual volumes of MAPs export and import in Poland in 2000-2019 (source: UN Comtrade database, own calculation)

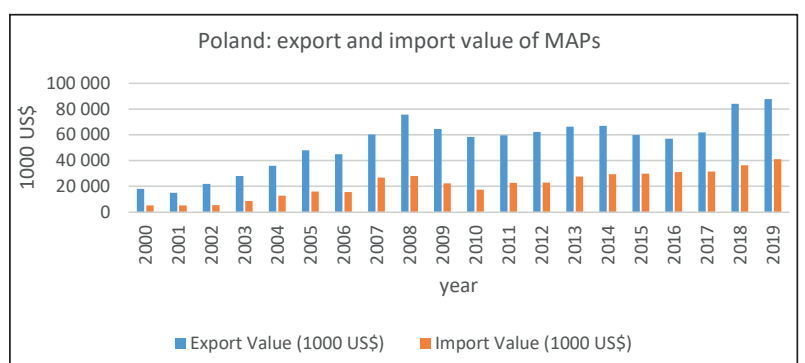

Figure 3.

Annual values of MAPs export and import in Poland in 2000-2019 (source: UN Comtrade database, own calculation) 
of MAPs in Poland in last two decades, showing a significant and constant growth in both categories. The values of export and import calculated in USD have been growing substantially (fig. 3).

\section{Relevance of wild collection to the Polish MAP market}

There is no accurate and recent data on the volume and share of MAPs deriving from WC and from cultivation in Poland. The latest estimation is a total of up to 30,000 tons annually [4, 5]. Jambor [5] has calculated that for 2002-2006, 17,000 tons of MAPs were cultivated annually, whereas $3000-5000$ tons of MAPs derive from WC $[5,6]$. Although there are major regional differences, firms producing MAPs in the north-east of Poland "source between 20 and 60\% of plant material volume from nature" [7]. However, a general trend in Poland represents a constant transfer of relevant MAP species from WC to cultivation $[5,8]$. In 2012, 70 MAP species have been cultivated [9], the most important ones were Hypericum perforatum, Valeriana officinalis, Arnica montana. Still, at least 100 traded species come from nature $[5,10]$. However, the potential of wild growing MAPs for commercial use could be much higher. For instance, nearly 450 species out of a total of estimated 2500 naturally occurring vascular plants in Poland [11] have medicinal properties [12].

In following chapters, we provide an overview on the regulations of the commercial wild collection of MAPs in Poland. Second, the supply chain of the wild collected MAPs, typical for the Polish market is presented in detail. Special attention is paid to two chain elements, i.e. collectors and purchase centres, directly or indirectly dependent on the companies specialised in the wild collection of MAPs. Then, the information relevant to the collection of the protected MAPs is presented. Later, presented data; socio-environmental implications; quality, sustainability and transparency issues, as well as challenges associated with them are discussed. Finally, an overview of the future perspectives for the Polish MAP market of the wild-sourced plants is provided.

\section{MATERIALS AND METHODS}

Due to lack of the centralised monitoring of total commercial collection of MAPs in Poland, information about harvested species, quantities, location of collection are sparse. To analyse the system of commercial wild collection, various methods of data gathering were utilised.

In 2017, all 16 Regional Directorates of Environmental Protection ( $R D O S$ ) in Poland, responsible for collection and monitoring of protected species and permission granting, were contacted. The aim was to obtain information about commercially collected MAPs under protection. The directorates were asked to provide the lists of medicinal plant species requested every year by the companies for collection, annual amounts of collected dried plant material, and an approximate location of collection. This information was requested from the consecutive five years (2012-2016) before and after change of the Plant Species Protection Act in 2014 [13]. To obtain the list of certified organic farms and companies specialising in the wild collection of MAPs, the Agricultural and Food Quality Inspection Main Inspectorate (IJHARS), was contacted in 2018.

In order to understand the structure of the MAPs WC system in Poland, a combination of methods was applied. In 2017, semi-structured interviews with the representatives of three well-recognised herbal companies were conducted. All three companies were set up just after the political transformation in Poland in 1989 and have a huge experience in WC. Two of them are based in north-east of Poland and one in Greater Poland. The interviews aimed at obtaining information about collected species, organisation of WC by the company, perception of WC's current situation in the company, predictions, challenges and opportunities in commercial WC. Additionally, three storage points (purchase centres) in the north-east of Poland, were visited and local managers were interviewed. That was accomplished in two consecutive years: 2017 and 2018 in order to account for annual changes. The interviews were focused on traded species and organisation of the storage points. In the same area, structured interviews were conducted with twentyfive collectors of MAPs, for which snowball sampling was used. Questionnaires aimed at determining species knowledge of the collectors, methods of collection and drying, socio-economic situation of the collectors and training opportunities available to them.

All calculated MAP market data (volumes and values) in this paper for the European and international trade derive from the US Comtrade Database (available at https://comtrade.un.org/data/, accessed 01.10.2020) and refer to the HS 1211 commodity code. This code specifically addresses "plants and parts of plants (including seeds and fruits), of a kind used primarily in perfumery, in pharmacy or for insecticidal, fungicidal or similar purposes, fresh or dried, whether or not cut, crushed or powdered". 
Additionally, all relevant legislation, including international agreements and national acts were reviewed. Applicable certification schemes, e.g. EU organic certification and "FairWild", focusing on wild collection of MAPs, were studied. The documents were reviewed to assess the coherence of actual WC system with them.

Ethical approval: The conducted research is not related to either human or animal use.

\section{RESULTS}

\section{Wild collection of MAPs in Poland: legislation and standardisation}

MAP collection for commercial purposes in Poland is regulated on several levels. Since Poland is an EU member and has adopted international standards and regulations, corresponding legal obligations have to be complied with. For instance, compliance with CBD [14], CITES [15], IUCN "European Red List of Medicinal Plants" [16] and EU Habitats Directive [17] is required in commercial collection of wild species. Overall, these documents aim to prevent overharvesting, species endangerment, and illegal trade. The guidelines of the Good Agricultural and Collection Practice (GACP) by WHO [18] and EMA [19] provide a backbone for regulating wild collection of medicinal plants.

Commercial MAP acquisition from natural sites in Poland is also regulated by the national law.
However, there is no unified document considering all species collected from nature. Rules for commercial harvesting of MAPs are included in various legal documents. Moreover, there is no centralised institution, which is controlling and documenting all wild collection of MAPs in Poland.

To provide a comprehensive overview of the legislation and monitoring of MAP wild collection in Poland, we take the MAP perspective and distinguish several, partially overlapping groups of MAPs (fig. 4, 5).

First, there is a group of protected species regulated by Plant Species Protection Act [13] and Nature Protection Act [20] (fig. 4) for which the collection is monitored by $R D O S$ (fig. 5). Second, commercial collection of MAPs from forests is regulated by specific laws: the Forest Act [21] and the Forest Groundcover Collection Act [22]. Parts of these acts that relate to commercial collection are short and imprecise, causing various interpretations. According to Forest Act [21] and Forest Groundcover Collection Act [22], local forester monitors commercial collection of the groundcover in State Forests (fig. 5).

In addition, there are specific norms regulating commercial collection of MAPs occurring in protected areas (e.g. national parks, nature reserves) included in abovementioned national Nature Protection Act [20]. Collection in nature reserves is allowed only with permission of an environmental agency (RDOŚ), whereas in national parks, commercial collection is possible in places indicated by its director (fig. 5).

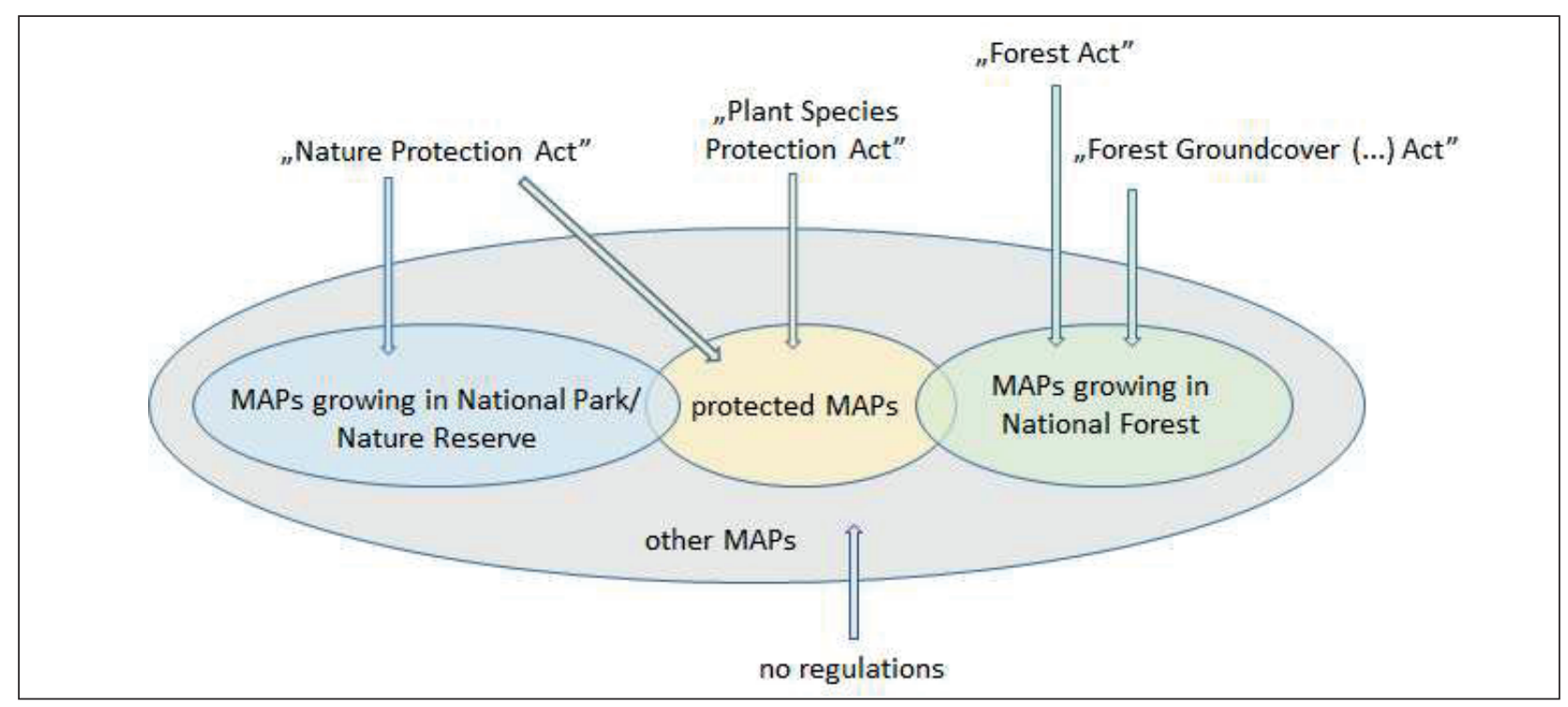

Figure 4.

Groups of MAP species, according to the regulating legislation (source: own compilation) 


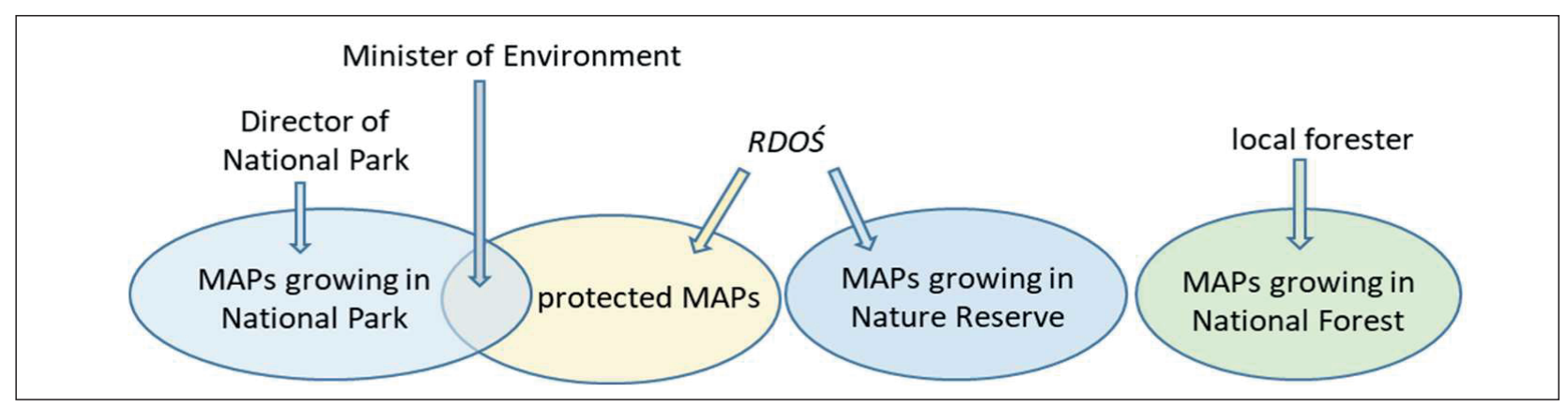

Figure 5.

Groups of MAP species, according to the monitoring authority (source: own compilation)

An unique situation occurs when protected MAP species (e.g. Menyanthes trifoliata) grow within the perimeter of a national park. According to the main Nature Protection Act (20) in such case commercial collection of a species requires permission from the Minister of Environment (fig. 5).

Finally, there is a vast group of MAPs which could grow in different sites than the State Forests and do not match with any species or spatial protection category (fig. 4); examples are: Crataegus sp., Agrimonia eupatoria, Filipendula ulmaria, Equistum arvense, or Artemisia absinthium. As a consequence, the commercial harvesting of such species is not monitored.

Wild collection of MAPs for trade can also be regulated by certification systems. Examples are the EU organic certification scheme (designed for ecological agriculture) or the "FairWild" certification standard, dedicated to sustainable collection of MAPs from nature. Organic standards are defined by European regulation [23], and by national regulation on organic agriculture [24]. This certification is designed to ensure a high ecological quality of the products and sustainability of production. This type of regulation is de facto self-regulation as the decision to adopt such standards is usually made at a company level. In 2018, organic certification in Poland was offered by six private certifying companies, accredited by the Ministry of Agriculture. The certifying companies have to inspect each of the certified companies at least once a year and are obliged to submit regular reports to the Agricultural and Food Quality Inspection Main Inspectorate (IJHARS). The "FairWild" Standard was founded by the FairWild Foundation in 2010 [25, 26]. This standard encompasses sustainable collection, social responsibility, including fair trade principles. The "FairWild" Standard is recognised as the best-practice framework for implementation of the UN Global Strategy for Plant Conservation [14].

\section{Wild collection of MAPs in Poland: supply structure and socio-ecological aspects}

The general structure of a supply chain and flow of MAP material sourced in nature in Poland (fig. 6) reveals varying degrees of control over organisation of sourcing. It seems that the companies (here "raw plant material company") have the main agency to shape the wild collection system in sourcing areas.

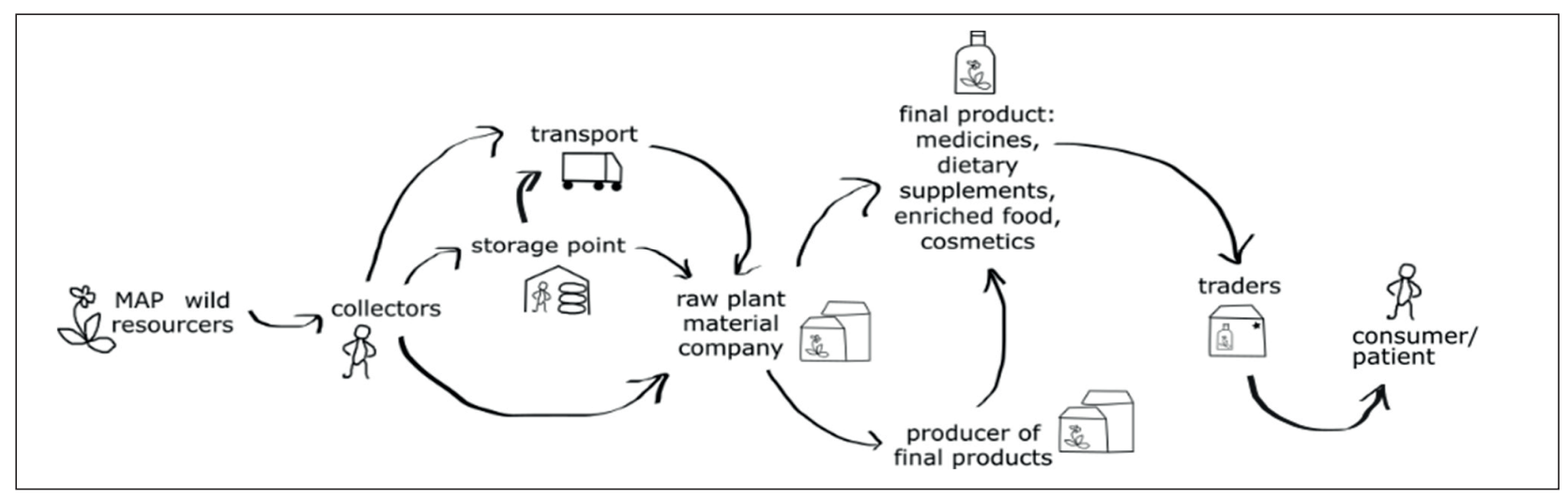

Figure 6.

Flow and supply chain of wild collected MAPs in Polish market (source: own compilation) 


\section{Raw plant material companies}

The business sector is presented on the fig. 6 as the "raw plant material company" - RPMC, since the plant material such companies obtain is provided unprocessed, except for drying, which often takes place at lower levels of the supply chain. Companies manufacture final MAP products and/or function as intermediaries, providing raw plant material to other businesses. Experiences drawn from our visits of the companies show that quality and type of produced herbal products may vary. Two companies partly rely on wild collection, partly on cultivated material. These two companies manufacture MAP products: dietary supplements and food. The third company recently switched its resource base from wild plant resources to cultivation, and currently manufactures mainly herbal medicinal products. The main reason for the new sourcing strategy is articulated as follows: "We could not rely anymore on wild collected plant material adulterated by other species or of bad quality" [27]. Herbal medicinal products have much higher requirements in terms of quality, safety control, and standardisation of active ingredients: "These standards are difficult to meet while sourcing in nature" [27].

Only enterprises manufacturing non-medical herbal products (derived either from wild collection or from cultivation) can obtain an EU organic certificate $[23,27,28]$. The Agricultural and Food Quality Inspection Main Inspectorate stated that 13 companies in Poland, sourcing MAPs in nature, possessed an organic certificate in 2018 . That comprised $0.07 \%$ of all Polish agricultural producers possessing ecological certificates [29]. Two companies contacted for this study possess organic certificates for their products and one - a "FairWild" certificate. In 2018, only seven companies were selling "FairWild"-certified ingredients worldwide.

Organisation of wild collection by company looks as follows. In the beginning of the vegetation season, usually in April, a RPMC announces the list of species and prices per kg of demanded MAPs. During the collection season, collectors supply plant material either directly to the companies (if living nearby), or to purchasing centres. Often companies acquire plant material collected in a different part of the country. In that case, centres/storage points are set in the collection regions.

\section{Purchase centres/storage points}

Storage points are organised predominantly in villages surrounded by well-preserved natural sites, in the area inhabited by a large number of collectors. The decision to set up a purchase centre usually results from a long-time experience of a company in given area. One of the companies reviewed in this study has 30 storage points scattered across Eastern Poland. As a rule, the collection is maintained by a local manager who usually is employed by the company on a seasonal basis, and receives regular updates relevant for the wild collection in the area, e.g. changes in regulation, permission- or market-related information. To organise the collection, the company provides and updates monthly lists of demanded MAPs; supplies tools and materials, e.g. paper/tow sacks, labels etc.; trains local managers and collectors (at best once a year, at the beginning of the season). The studied storage points are supplied by 15-20 collectors. For each purchase centre, collectors are known by surname (to improve traceability of the plant material). The responsibilities of the local manager include: physical quality control of the purchased plant material, maintenance of the plant identification system, labelling, documentation of the process, funds management, ensuring proper storage conditions. In storage points of the companies holding organic and/or the "FairWild" certificate, there is always a map identifying areas for plant collection.

\section{Collectors}

According to the questionnaire responses, $68 \%$ of interviewed collectors were women. The age of collectors varied from 35 to 91 . Married couples often collect plants together. $73 \%$ of informants were retired, for the other $27 \%$ collection of MAPs was an additional source of income (after farming). Most of collectors started harvesting wild plants in their childhood, accompanying their parents. A few women who started collecting during retirement, gained botanical and harvesting knowledge from herbal books, neighbours, or the internet. During collection season, collectors spend up to four hours a day in the field, usually in the morning. Nearly half of them harvest MAPs almost every day, nearly $30 \%$ of informants 10-15 days a month, $20 \%$ up to five days per month.

In general, collectors were not hired by the companies in any form, but were selling plant material they have harvested. Similar structure is applied in other RPMCs not included in this study [28, 30]. According to the questionnaire responses, wild collection of herbs can provide additional monthly income equal to average monthly retirement pension (circa $350 €$ ). Both collectors and companies confirmed that a decade ago, prices proposed by 
companies were highly attractive for rural people $[28,30]$. Companies indicated that the social support programme "Rodzina 500+" introduced by the government in 2016 is a major reason for declining financial attractiveness (and necessity) of MAP collection by younger generation and not employed women $[28,30,31]$.

Out of 25 MAP collectors interviewed for this study, only $16 \%$ have undergone a professional GACP training at least once in their life, organized by a company in a purchase centre. In analysed cases, training of collectors covered GACP and other rules incorporated in certification, i.e. organic or "FairWild", but only if company labels its product in this way. According to the interviewed leaders of companies mentioned, collectors usually do not request any training on botanical or ecological issues: "most of the collectors are villagers, so they know plants and where they grow" $[28,30]$.

A purchase centre usually buys plants in a dry form, so that collectors are responsible for drying process. Usually plants are dried in an attic at home or in an outbuilding. The process is conducted according to common rules in European herbal literature, ensuring drying conditions of cleanliness, no sunlight exposure and good airing. "The drying process depends on the plant and may take a few days" - collectors reported. Collectors decide where, when and how MAP plant material is collected, dried and stored. In case collectors live close to a company, harvested plant material is sold directly to the company, where MAPs are dried using industrial facilities. All the supply steps before MAPs material is sold to the RPMC, are recognised by the authors as key elements impacting MAPs quality, sustainability and labour standards.

\section{Wild collection of MAPs in Poland: species}

According to the companies' representatives interviewed in this study, the number of wild collected plants vary from 125 to 140 species. Table 4 lists 116 species harvested in nature and parts of collected plants, including chaga mushroom (Inonotus obliquus) and naturalised garden plants, e.g. common jasmine (Jasminum officinale) and flowering quince (Chaenomeles sp.). Usually collectors bring and sell

Table 3.

The list of MAPs under different protection categories in Poland 2004-2014 and 2015-2020 (own compilation based on [33] and [13])

\begin{tabular}{llccllcc}
\hline \multicolumn{1}{c}{ Species } & $2004-2014$ & $2015-2020$ & \multicolumn{2}{c}{ Species } & $2004-2014$ & $2015-2020$ \\
\hline 1 & Aconitum sp. & $\mathrm{SP}$ & $\mathrm{PP}$ & 22 & Gentiana sp. & $\mathrm{SP}$ & $\mathrm{SP}$ \\
\hline 2 & Adonis vernalis & $\mathrm{SP}$ & $\mathrm{SP}$ & 23 & Hedera helix & $\mathrm{PP}$ & $\mathrm{NP}$ \\
\hline 3 & Allium ursinum & $\mathrm{SP}$ & $\mathrm{PPC}$ & 24 & Helichrysum arenarium & $\mathrm{PPC}$ & $\mathrm{PPC}$ \\
\hline 4 & Angelica archangelica & $\mathrm{SP}$ & $\mathrm{PP}$ & 25 & Hierochloe australis & $\mathrm{PPC}$ & $\mathrm{PPC}$ \\
\hline 5 & Arctostaphylos uva-ursi & $\mathrm{SP}$ & $\mathrm{SP}$ & 26 & Hierochloe odorata & $\mathrm{PP}$ & $\mathrm{PPC}$ \\
\hline 6 & Arnica montana & $\mathrm{SP}$ & $\mathrm{SP}$ & 27 & Hippophae rhamnoides & $\mathrm{SP}$ & $\mathrm{PPC}$ \\
\hline 7 & Arum maculatum & $\mathrm{SP}$ & $\mathrm{SP}$ & 28 & Ledum palustre & $\mathrm{SP}$ & $\mathrm{PP}$ \\
\hline 8 & Asarum europaeum & $\mathrm{PPC}$ & $\mathrm{NP}$ & 29 & Melittis melissophyllum & $\mathrm{NP}$ & $\mathrm{PP}$ \\
\hline 9 & Atropa belladonna & $\mathrm{SP}$ & $\mathrm{PP}$ & 30 & Menyanthes trifoliata & $\mathrm{PPC}$ & $\mathrm{PPC}$ \\
\hline 10 & Carlina acaulis & $\mathrm{SP}$ & $\mathrm{PP}$ & 31 & Myrica gale & $\mathrm{SP}$ & $\mathrm{SP}$ \\
\hline 11 & Centaurium erythraea & $\mathrm{NP}$ & $\mathrm{PP}$ & 32 & Ononis spp. & $\mathrm{SP}$ & $\mathrm{PP}$ \\
\hline 12 & Cetraria islandica & $\mathrm{PPC}$ & $\mathrm{PPC}$ & 33 & Polemonium caeruleum & $\mathrm{SP}$ & $\mathrm{SP}$ \\
\hline 13 & Cimicifuga europaea & $\mathrm{SP}$ & $\mathrm{PP}$ & 34 & Primula elatior & $\mathrm{SP}$ & $\mathrm{PP}$ \\
\hline 14 & Colchicum autumnale & $\mathrm{SP}$ & $\mathrm{PP}$ & 35 & Primula veris & $\mathrm{PP}$ & $\mathrm{NP}$ \\
\hline 15 & Convallaria mayalis & $\mathrm{PPC}$ & $\mathrm{NP}$ & 36 & Ribes nigrum & $\mathrm{PPC}$ & $\mathrm{NP}$ \\
\hline 16 & Digitalis grandiflora & $\mathrm{SP}$ & $\mathrm{PP}$ & 37 & Scopolia carniolica & $\mathrm{SP}$ & $\mathrm{PP}$ \\
\hline 17 & Drosera sp. & $\mathrm{SP}$ & $\mathrm{SP}$ & 38 & Taxus baccata & $\mathrm{SP}$ & $\mathrm{PP}$ \\
\hline 18 & Eryngium maritimum & $\mathrm{SP}$ & $\mathrm{SP}$ & 39 & Veratrum album & $\mathrm{SP}$ & $\mathrm{SP}$ \\
\hline 19 & Frangula alnus & $\mathrm{PPC}$ & $\mathrm{NP}$ & 40 & Veratrum nigrum & $\mathrm{SP}$ & $\mathrm{SP}$ \\
\hline 20 & Fucus vesiculosus & $\mathrm{SP}$ & 41 & Viburnum opulus & $\mathrm{PP}$ \\
\hline 21 & Galium odoratum & $\mathrm{NP}$ & 42 & Vinca minor & $\mathrm{NP}$ \\
\hline
\end{tabular}

SP - strict protection; PP - partial protection; PPC - partial protection with option of collection after obtaining a permission; NP - no protection, collection allowed; dark background - collection forbidden; light background - possibility of collection under various conditions 
Table 4.

List of traded Medicinal and Aromatic Plants and parts of plants that are collected from natural habitats in Poland (source: own compilation, based on various species listings from the three purchase centres visited in 2017-2018)

\begin{tabular}{|c|c|c|c|c|c|c|c|c|}
\hline $\mathrm{Nr}$ & MAP species & $\begin{array}{c}\text { Plant } \\
\text { part }\end{array}$ & $\mathrm{Nr}$ & MAP species & $\begin{array}{c}\text { Plant } \\
\text { part }\end{array}$ & $\mathrm{Nr}$ & MAP species & $\begin{array}{r}\text { Plant } \\
\text { part }\end{array}$ \\
\hline 1 & Achillea millefolium $\mathrm{L}$. & FL & 39 & Galium mollugo L. & $\mathrm{H}$ & 76 & Prunus spinosa $\mathrm{L}$. & FL/FR \\
\hline 2 & Acorus calamus L. & RH & 40 & Galium odoratum (L.) Scop. & $\mathrm{H}$ & 77 & Pulmonaria obscura Dumort. & $\mathrm{FO} / \mathrm{H}$ \\
\hline 3 & Aegopodium podagraria $\mathrm{L}$. & $\mathrm{H}$ & 41 & Gelium verum $\mathrm{L}$. & $\mathrm{H}$ & 78 & Quercus robur $\mathrm{L}$. & $\mathrm{C} / \mathrm{FR}$ \\
\hline 4 & Aesculus hippocastanus L. & $\mathrm{FL} / \mathrm{C} / \mathrm{FR}$ & 42 & Genista tinctoria $\mathrm{L}$. & $\mathrm{H}$ & 79 & Ribes nigrum $\mathrm{L}$. & FO \\
\hline 5 & Agrimonia eupatoria L. & $\mathrm{H}$ & 43 & Geranium robertianum $\mathrm{L}$. & $\mathrm{H}$ & 80 & Robinia pseudoacacia L. & FL \\
\hline 6 & Agropyron repens (L.) Gould & $\mathrm{RH}$ & 44 & Glechoma hederacea L. & $\mathrm{H}$ & 81 & Rosa ssp. & FL/FR \\
\hline 7 & Alchemilla ssp. & $\mathrm{H}$ & 45 & Hedera helix L. & $\mathrm{FO}$ & 82 & Rubus ssp. & $\mathrm{FO}$ \\
\hline 8 & Arctium lappa $\mathrm{L}$. & RA & 46 & Helichrysum arenarium (L.) Moench. & FL & 83 & Rubus idaeus & $\mathrm{FO} / \mathrm{FR}$ \\
\hline 9 & Artemisia absinthium L. & $\mathrm{H}$ & 47 & Herniaria glabra $\mathrm{L}$. & $\mathrm{H}$ & 84 & $\begin{array}{l}\text { Rumex hydrolapathum Huds. } \\
\text { and others }\end{array}$ & RA \\
\hline 10 & Artemisia vulgaris L. (Mattf.) & $\mathrm{H}$ & 48 & Hierochloe odorata (L.) P. Beauv. & FL & 85 & Salix alba $\mathrm{L}$. & $\mathrm{C} / \mathrm{FO}$ \\
\hline 11 & Asarum europaeum L. & $\mathrm{H}$ & 49 & Hypericum perforatum $\mathrm{L}$. & $\mathrm{H}$ & 86 & Salix purpuraea L. & $\mathrm{C}$ \\
\hline 12 & Astragalus glycyphyllos L. & $\mathrm{H}$ & 50 & Inonotus obliquus Pilát & M & 87 & Sambucus nigra L. & FL/FR \\
\hline 13 & Bellis perennis $\mathrm{L}$. & FL & 51 & Jasminum officinale $\mathrm{L}$. & FL & 88 & Sanguisorba officinalis $\mathrm{L}$. & $\mathrm{H}$ \\
\hline 14 & Berberis vulgaris $\mathrm{L}$. & $\mathrm{T}$ & 52 & Juglans regia $\mathrm{L}$. & $\mathrm{FO}$ & 89 & Saponaria officinalis $\mathrm{L}$. & RA \\
\hline 15 & Betonica officinalis L. & $\mathrm{H}$ & 53 & Juniperus communis $\mathrm{L}$. & FR & 90 & Solidago ssp. & $\mathrm{H}$ \\
\hline 16 & Betula pendula Roth. & $\mathrm{FO} / \mathrm{C} / \mathrm{G}$ & 54 & Lamium album $\mathrm{L}$. & $\mathrm{FL} / \mathrm{H}$ & 91 & Sorbus aucuparia $\mathrm{L}$. & $\mathrm{FL} / \mathrm{FR}$ \\
\hline 17 & Bidens tripartita $\mathrm{L}$. & $\mathrm{H}$ & 55 & Leonurus cardiaca L. & $\mathrm{H}$ & 92 & Stachys sylvatica $\mathrm{L}$. & $\mathrm{H}$ \\
\hline 18 & Calluna vulgaris (L.) Hull. & $\mathrm{FL} / \mathrm{H}$ & 56 & Lycopus europaeus $\mathrm{L}$. & $\mathrm{H}$ & 93 & Stellaria media (L.) Vill. & $\mathrm{H}$ \\
\hline 19 & Capsella bursa-pastoris (L.) Medik. & $\mathrm{H}$ & 57 & Malus domestica Borkh. & FR & 94 & Symphytum officinale $\mathrm{L}$. & RA \\
\hline 20 & Centaurea cyanus L. & FL & 58 & Melilotus officinalis (L.) Pall. & $\mathrm{H}$ & 95 & Tanacetum vulgare $\mathrm{L}$. & FL \\
\hline 21 & Chaenomeles ssp. & FR & 59 & Menyanthes trifoliata $\mathrm{L}$. & FO & 96 & Taraxacum ssp. & $\mathrm{FL} / \mathrm{FO} / \mathrm{H} / \mathrm{RA}$ \\
\hline 22 & Chelidonium majus L. & $\mathrm{H} / \mathrm{RA}$ & 60 & Nepeta cataria L. & $\mathrm{H}$ & 97 & $\begin{array}{l}\text { Thymus pulegioides } \mathrm{L} . / T \text {. } \\
\text { serpyllum } \mathrm{L} \text {. }\end{array}$ & $\mathrm{H}$ \\
\hline 23 & Cichorium intybus L. & RA & 61 & Odontites vernus subsp. serotinus Corb. & $\mathrm{H}$ & 98 & $\begin{array}{l}\text { Tilia cordata Mill./T. } \\
\text { platyphyllos Scop. }\end{array}$ & $\mathrm{FO} / \mathrm{C} / \mathrm{G}$ \\
\hline 24 & Cirsium oleraceum (L.) Scop. & $\mathrm{H}$ & 62 & Ononis spinosa $\mathrm{L}$. & RA & 99 & Trifolium pratense $\mathrm{L}$. & FL \\
\hline 25 & Corydalis ssp. & $\mathrm{H}$ & 63 & Papaver rhoeas L. & $\mathrm{FL}$ & 100 & Trifolium repens $\mathrm{L}$. & $\mathrm{FL}$ \\
\hline 26 & Coryllus avelana $\mathrm{L}$. & $\mathrm{FO}$ & 64 & Phaseolus vulgaris $\mathrm{L}$. & FR & 101 & Tussilago farfara $\mathrm{L}$. & $\mathrm{FL} / \mathrm{FO}$ \\
\hline 27 & $\begin{array}{l}\text { Crataegus monogyna Jacq./C. } \\
\text { laevigata (Poir.) DC }\end{array}$ & $\mathrm{FL} / \mathrm{FR}$ & 65 & Pimpinella saxifraga $\mathrm{L}$. & RA & 102 & Urtica dioica $\mathrm{L}$. & $\mathrm{FO} / \mathrm{H} / \mathrm{RA}$ \\
\hline 28 & Epilobium palustre $\mathrm{L}$. & $\mathrm{H}$ & 66 & Pinus sylvestris $\mathrm{L}$. & $\mathrm{G} / \mathrm{N}$ & 103 & Vaccinium myrtillus $\mathrm{L}$. & $\mathrm{FO} / \mathrm{H} / \mathrm{FR}$ \\
\hline 29 & Epilobium parviflorum Schreb. & $\mathrm{H}$ & 67 & Plantago lanceolata L./P. major $\mathrm{L}$. & FO & 104 & Vaccinium vitis-idaea $\mathrm{L}$. & $\mathrm{FO}$ \\
\hline 30 & Equisetum arvense $\mathrm{L}$. & $\mathrm{H}$ & 68 & Polygonum aviculare $\mathrm{L}$. & $\mathrm{H}$ & 105 & Verbascum ssp. & $\mathrm{FL}$ \\
\hline 31 & Euphrasia rostkoviana Hayne & $\mathrm{H}$ & 69 & Plygonum bistorta $\mathrm{L}$. & RA & 106 & Veronica chamaedrys L. & $\mathrm{H}$ \\
\hline 32 & Filipendula ulmaria (L.) Maxim. & $\mathrm{FL} / \mathrm{H}$ & 70 & Populus nigra L. & G & 107 & Veronica officinalis L. & $\mathrm{H}$ \\
\hline 33 & Fragaria vesca $\mathrm{L}$. & $\mathrm{FO} / \mathrm{FR}$ & 71 & Potentilla anserina $\mathrm{L}$. & $\mathrm{H}$ & 108 & Viburnum opulus L. & $\mathrm{C}$ \\
\hline 34 & Frangula alnus Mill. & $\mathrm{C}$ & 72 & Potentilla ssp. & $\mathrm{H}$ & 109 & Viola odorata L. & $\mathrm{FL}$ \\
\hline 35 & Fraxinus excelsior L. & $\mathrm{FO} / \mathrm{C}$ & 73 & Potentilla erecta (L.) Raeusch. & RH & 110 & Viola sylvestris Rchb. & $\mathrm{FL}$ \\
\hline 36 & Fumaria officinalis $\mathrm{L}$. & $\mathrm{H}$ & 74 & Primula veris $\mathrm{L}$. & FL & 111 & Viola tricolor $\mathrm{L}$. & $\mathrm{H}$ \\
\hline 37 & Galeopsis tetrahit $\mathrm{L}$. & $\mathrm{H}$ & 75 & Prunella ssp. & $\mathrm{H}$ & 112 & Viscum album $\mathrm{L}$. & $\mathrm{H}$ \\
\hline 38 & Galium aparine $\mathrm{L}$. & $\mathrm{H}$ & 75 & Prunella ssp. & $\mathrm{H}$ & & & \\
\hline
\end{tabular}

Species not growing naturally in the wild habitats are marked bold). FL - flos, $\mathrm{H}-$ herba, FO - folium, FR - fructus, RH - rhizome, RA - radix, C cortex, $\mathrm{G}$ - gemma, $\mathrm{T}$ - twigs, $\mathrm{N}$ - needle, $\mathrm{M}$ - mushroom 
MAPs to the purchase centres from April to October/November. At the beginning of the collection season, mainly roots and bark of MAPs can be sold. In summer, the lists of species and of traded plant parts are the longest; in autumn mainly fruits are bought. The end of the collection season is usually marked by selling fruits of Aesculus hippocastanus or Quercus sp.

\section{Wild collection of MAPs in Poland: protected species}

Currently, 715 plant species are protected in Poland, including algae, bryophytes, ferns and vascular plants [13]. In the Plant Species Protection Act [13], two main protection categories are distinguished: strict protection and partial protection. The species listed in the first category cannot be collected for any use or trade (Annex 1 to the act). The act indicates other limitations and bans for the collection of species of the first category. In fact, very similar restrictions are applied for 300 species under partial protection (Annex 2 to the act). There is an exception for 12 species which are partly protected (listed in Annex 3 to the act), the only species that can be collected if permission is obtained.

A collecting entity (usually company) needs to obtain a permission from one of the 16 Regional Directories of Environmental Protection $(R D O S)$ prior to harvest. The permission can be issued for a maximum of five years, however, usually it is granted only for a year. The list of partially protected plants, which can be collected after obtaining a permission, includes six moss species and the following MAP species: Allium ursinum, Hippophae rhamnoides, Helichrysum arenarium, Hierochloe australis, Hierochloe odorata, Menyanthes trifoliata.

The Mushroom Species Protection Act [32], besides mushroom species, includes and regulates the collection of medicinal lichen Cetraria islandica. Its collection also requires permissions from $R D O S$ (based on the similar rules as protected plants). The Plant Species Protection and the Mushroom Species Protection Act also indicate permitted methods of collection. Protected MAP species, collection of wich is strictly forbidden, are as follows: Angelica archangelica, Arctostaphylos uva-ursi, Arnica montana, Atropa belladonna, Centaurium erythraea, Cimicifuga europaea, Fucus vesiculosus, Ledum palustre, Ononis spinosa and others.

The law and the list of the species are updated in order to account for the changes in plant species population, the intensity of antropopressure (e.g. commercial collection) and the endangerment status of the species. Legislative protection of MAPs aims at preserving them in natural sites and protecting them from unsustainable and uncontrolled collection for private and, what is the most important, for commercial purposes, which is the predominant pressure factor on the MAPs populations. Table 3 presents how the category of protection for 42 MAPs (Plant Species Protection Act from 2004 [33]) changed after amendment in 2014 [13]. Before 2014, from all species listed in table 3,11 could be harvested legally, whereas since 2015, 16 species can be collected (7 of them with permission). In 2014, 12 MAP species were moved from the strict protection category to the partial protection. The other species (e.g.: Convallaria majalis, Primula veris, Ribes nigrum, Viburnum opulus) which were partly protected are not protected any more. In general, there is a distinct trend of loosening restrictions in MAPs' collection.

\section{Collection permissions}

From 2012 to 2016, 98 applications for collection permissions were submitted to 16 Regional Directories of Environmental Protection (RDOŚ) in all voivodeships in Poland. Only applications considering harvest of wild growing MAPs for commercial purposes have been counted (other purposes, e.g. "for research" were excluded). The majority of applications were filled in Podlaskie Province, ca. 10 applications annually (fig. 7). The major part of the total applications was submitted in regions on eastern border of Poland: Warmian-Masurian, Podlaskie, Lublin, and Subcarpathian. However, in the provinces like Pomeranian, Lubuskie, Lower Silesian, Greater Poland, Łódź, and Lesser Poland not a single application was submitted during five-year period. In Masovian Province, all applications were rejected. Applications for permission included up to 16 species. Menyanthes trifoliata was the most frequently requested species (fig. 8). In over $85 \%$ of cases, permissions for collection of this species were granted. In the case of Hierochloe odorata, a popular grass added to a local, famous vodka "Żubrówka" ca. $80 \%$ of requests were positively processed, whereas the same number of requests for collection of $\mathrm{Hi}$ erochloe australis was rejected. Submitted applications often concerned strictly protected and partly protected species, collection of which is forbidden (without exclusions). Surprisingly, received data show that sometimes agencies authorised collection in a wrong way. For example, in 2012-2014, collection of Hierochloe odorata (under partial 


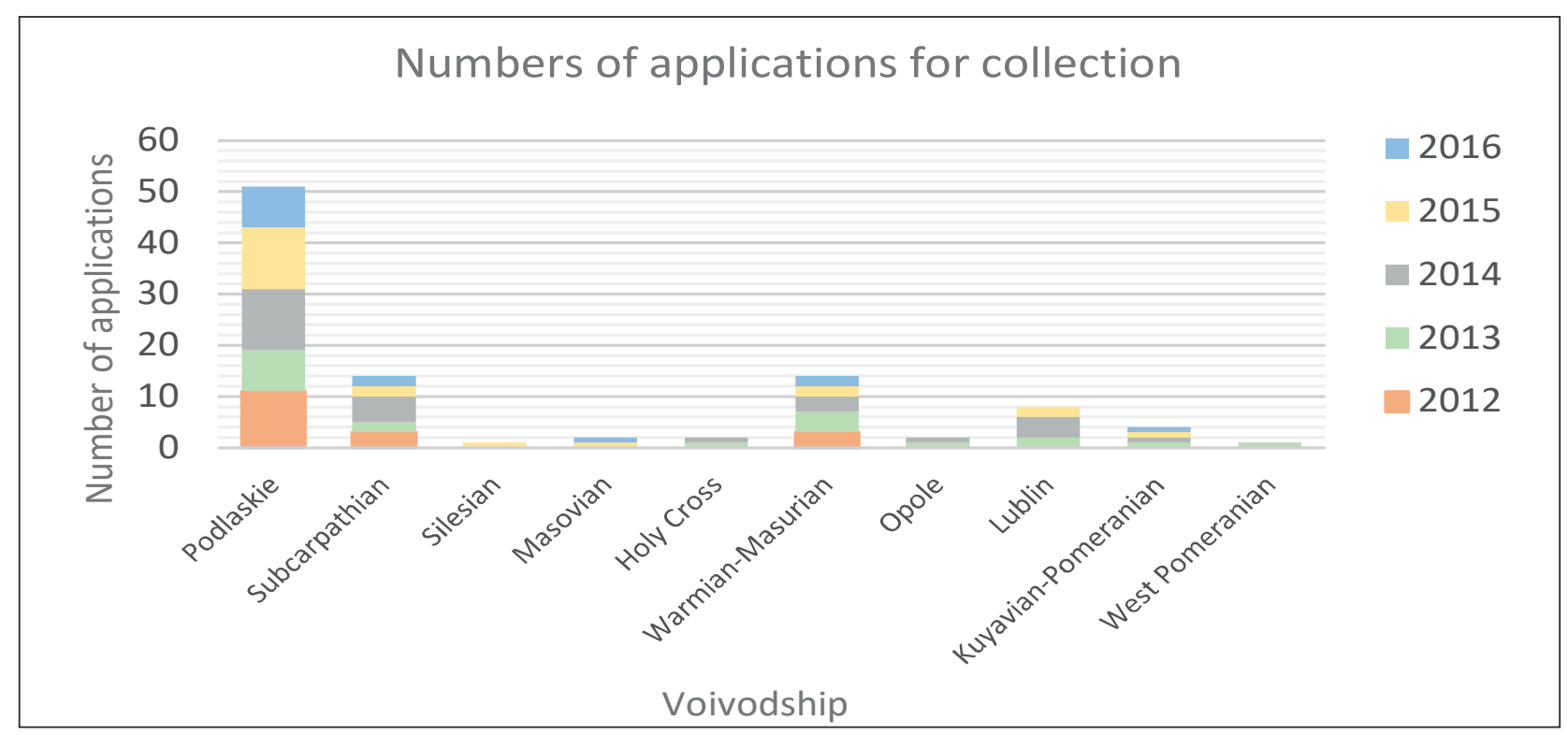

Figure 7.

The number of applications filed to RDOŚ, by herbal companies for wild collection of MAPs, in 2012-2016, by voivodeship (source: own calculations)

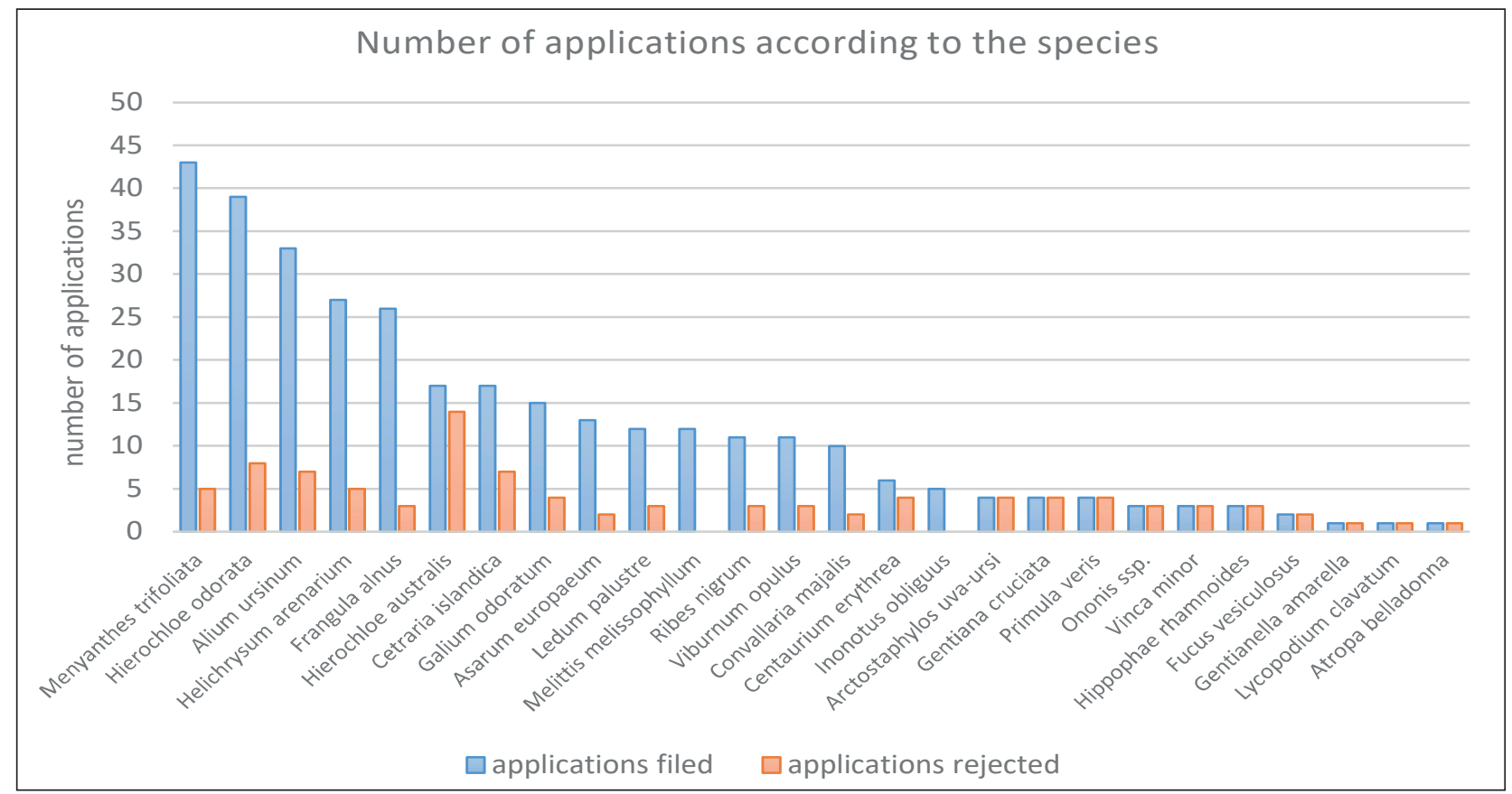

Figure 8.

Total number of applications and rejections according to the species, 2012-2016 (source: own calculations)

protection until 2014), in 2015 collection of Centaurium erythrea (under partial protection since 2015), in 2012-2016 collection of Ledum palustre (strictly protected species until 2014 and partly protected since 2015) were permitted. The mistakes did not concern large quantities, but the volumes up to several hundred kilograms of dried plant material in total (fig. 10).

\section{Collection of protected MAPs: provinces and quan-} tities

The largest harvest of protected MAPs in 2012-2016 was in Warmian-Masurian Voivodeship, exceeding 82 tons (fig. 9). All data presents the collection quantities of the dried plant material (DW) with one exception: the major part of the collection 


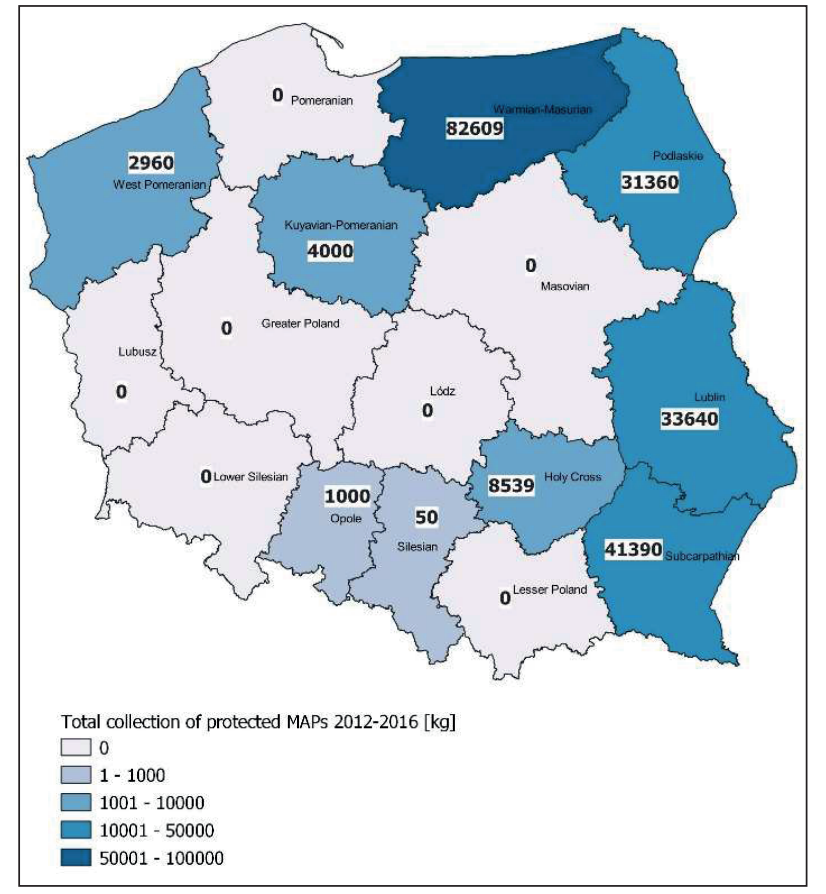

Figure 9.

Total quantities of protected MAPs collection in Polish voivodships in 2012-2016 (source: own calculations) of Menyanthes trifoliata (61 tons), corresponds to the wet plant material [WW]. The data on protected species collection indicates Eastern Poland as the main collection region.

The Podlaskie Region distinguishes itself by a relatively wide range of 15 collected protected plant species (fig. 10). Most of them had been harvested in the amount higher than 1 ton in 20122016. The Subcarpathian, Lublin, Warmian-Masurian, and Podlaskie Voivodeships are characterized by high amounts of harvested Frangula alnus bark, which in these regions reached 41, 29, 18 and 8 tons, respectively (fig. 10). Frangula alnus bark was collected in almost all regions in which collection of protected species took place. The leaves of Allium ursinum seem to be a commonly collected herbal plant material, nevertheless in much smaller amounts, with an exception in Świętokrzyskie Region (Holy Cross Region), where almost 8 tons were harvested in 2012 to 2016. The Hierochloe odorata grass was collected only in Podlaskie Region (ca. 1.5 ton). A typical wetland species $\mathrm{Me}$ nyanthes trifoliata was obtained from natural sites in five regions. The huge quantities of its leaves

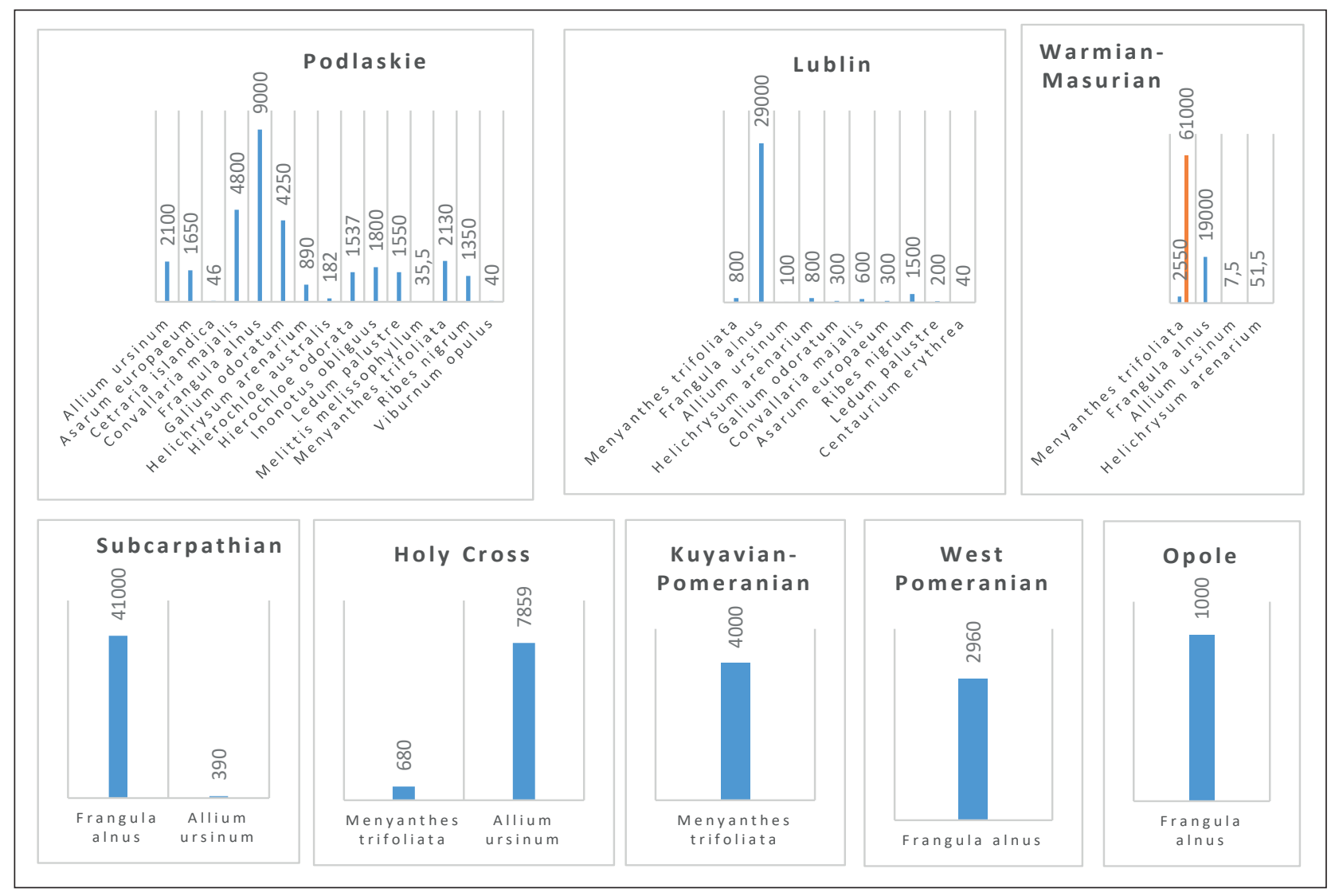

Figure 10.

Collected protected MAPs and their total quantities [blue - kg of DW, orange - kg of WW], differentiated by the voivodships, 2012-2016 (source: own calculations) 
(exceeding 63 tons) were harvested in WarmianMasurian Voivodeship, which is characterized by a high amount of lakes and rivers.

Harvest of Menyanthes trifoliata was steadily increasing every year from 2.1 tons in 2012 to almost 32 tons in 2016 (fig. 11). The collection of Allium ursinum leaves reached its peak in 2014, when over 8 tons were harvested. Although Ledum palustre was listed in the law as strictly protected species until 2014 (partially protected after 2014), ca. 250 to $500 \mathrm{~kg}$ of this species were collected each year. Linear growth of collection of Frangula alnus bark is visible. This plant material was harvested in the greatest quantities of all collected protected MAPs, starting from 25 tons in 2012 and almost reaching 46 tons in 2014 . Despite the growth of collection volumes, the law amendment from 2014 [13], drew Frangula al$n u s$ out of protection list and protected status. Consequently, the collection of this species has not been monitored and controlled since 2015. As a result, data concerning collection quantities and locations of occurrence is not available for this species. For other species that are no longer protected, collection volumes show downward trend in 2012-2014, except from Ribes nigrum, for which harvest of leaves was slightly growing.

\section{DISCUSSION}

\section{Polish MAP market: legislation and regulation}

The Polish system of MAP collection from nature can serve as a reference, mirroring similar situations in other post-communist countries in Europe. Poland still has vast rural areas with well-preserved natural sites. Poland also has a long and still practised tradition of wild collection of medicinal plants and household use of natural medicines derived from MAPs. We identify the demand for MAPsbased natural medicines as a main driver for the development of the market of medicinal products from wild collected MAPs. The development of this market is rooted back in communist times. The political and thus social and economic transformation of 1989 and the EU accession of Poland in 2004 reshaped the MAP market: laws were changed, new business opportunities emerged, market standards were re-defined, replaced and in general harmonised with EU standards. The present market in Poland is still dominated by few large companies, although a significant number of companies trading with wild collected MAPs started working in recent years. Based on our research on the collection

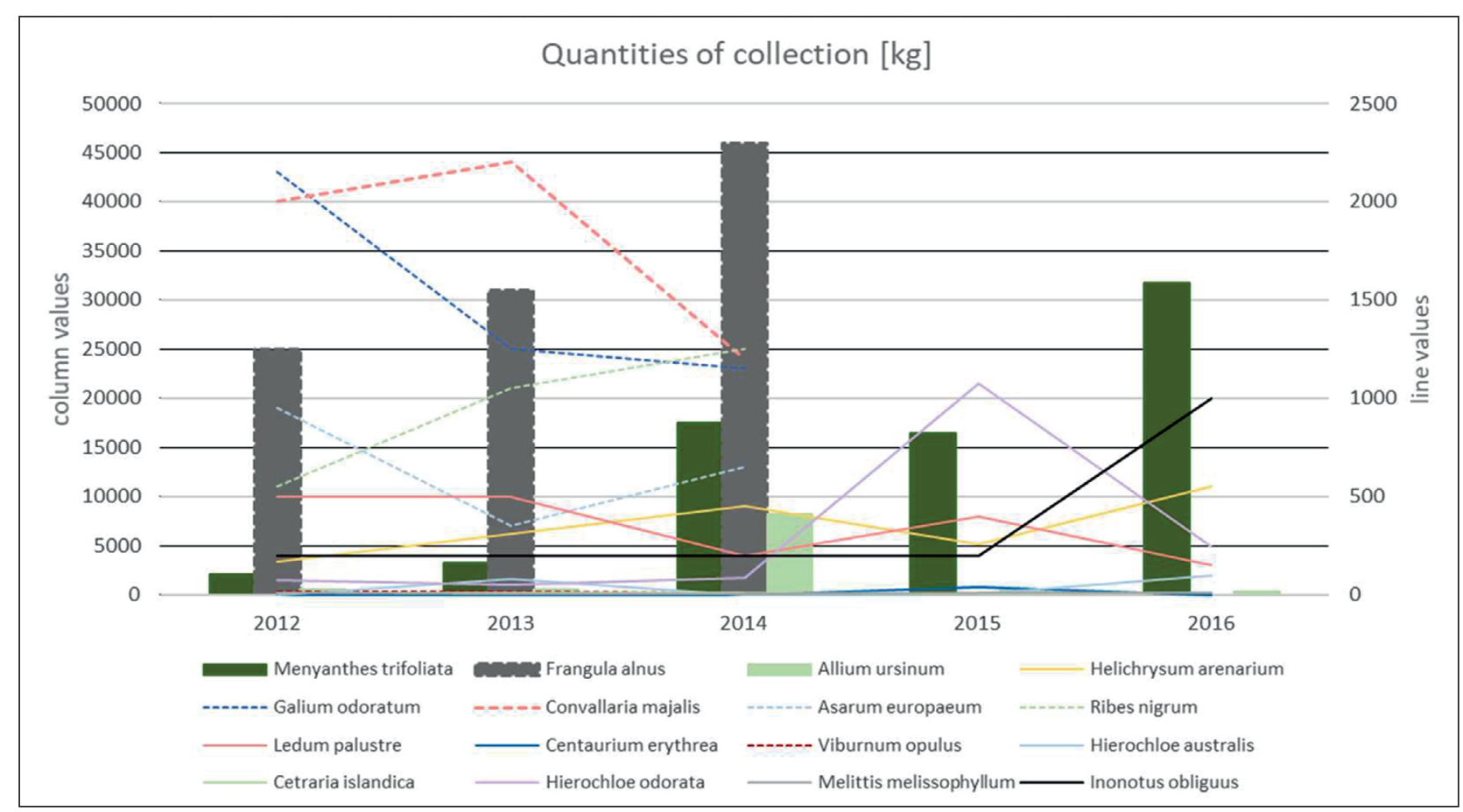

Figure 11.

Total collection of protected MAPs in Poland, 2012-2016. [The high values are represented by columns and assigned to the left $y$ axis, the lower values are presented by lines and are assigned to the right $y$ axis; with dashed lines and columns are distinguished species that are no longer protected since the law change in 2014 (13)] (source: own calculations) 
and processing of MAPs in Poland, we can state that commercial wild collection is concentrated in the eastern part of Poland. Overall, wild collection of MAPs plays a significant role in the Polish MAP market. Not only the MAP market numbers indicate general growth, but also interviewed company owners confirm that the demand for MAPs, including from wild collections, is growing on national and international markets.

We assume that: a) the structure of wild collection system has not changed much since communist times; b) laws regulating wild collection of MAPs lack coherence with practice and consistency; c) monitoring of collection does not cover all species and volumes; d) raw plant material companies lack economic, structural capacity and labour force to ensure sustainable management of important elements of the supply chain subordinated to or dependent on them. As a consequence, sustainability and quality problems arise. Furthermore, the market undergoes a transition where not medicines, but dietary supplements, enriched food and cosmetic products are supplied by MAP ingredients harvested in nature. Overall, the situation of commercial wild herb collection in Poland involves several areas of concern. We do conclude that sustainability, quality and management problems may arise as a result of lack of consistency and coherency of practice and implementation (including monitoring of collection) within the legal framework.

For example, the Forest Act [21] and the Forest Groundcover Collection Act [22] do not mention MAPs per se, but refer to them in a more general concept of "forest groundcover" to which some MAPs belong. According to these two acts [21, 22], "a purchase of the forest groundcover from State Forests requires a contract with a forest district". The groundcover "is observed in terms of any species endangerment" and "a forester can refuse to sign a contract, if collection endangers forest environment". In practice, if monitoring of the commercial collection of MAPs in national forest exists, it is performed locally and data on collected species, quantities of collection, and its location is generally not gathered. Therefore, it is impossible to get the complete overview of the collected volumes. Furthermore, the impact of collection activities on MAP populations, which occur in such forests, cannot be assessed. The studied companies sign contracts with the forest district administration if it is located close to the company's head office. In such cases, the companies collaborate according to the best law interpretation. It can be seen as a best practice example of organising wild collection. Nevertheless, if a company obtains MAP material in the net of purchase centres, it often does not sign contracts with foresters in the sourcing areas. In this case, collectors harvest MAPs freely from diverse habitats, including forests. As a consequence, collection in these forests is informal and not monitored. Collectors might be confronted by the forest district administration, when harvesting MAPs without any prior agreement. In addition, many MAPs not belonging to "forest ground cover" (e.g. Frangula alnus or Rubus nigra) occur in forests. It is not clear, if the commercial collection of such forest species requires contract with local forest administration as well. We conclude that two abovementioned forest acts $[21,22]$ are more often understood and applied to regulate commercial collection of wild berries and mushrooms (which is a differently structured system), than collection of MAPs. Therefore, we believe that abovementioned laws do not fully match to the purpose of regulating collection of MAPs in forests, as they leave loopholes and are prone to misinterpretation.

In the same way, we argue that the lack of clarity in the phrasing and specificity of the Nature Protection Act [20] allows for interpretation of the regulation of MAP collection in national parks. The Nature Protection Act (20) states, that "... it is not allowed (...) to collect wild growing plants (...) and their parts, except places designated by the director of the national park". Considerable land areas of national parks often belong to local people and are taken under "landscape protection". According to the law [20], in "landscape protection" areas, some of national park bans (e.g. ban for plant collection) are not valid during agricultural work. It is not clear if the collection of MAPs can be referred to agricultural work and can be practised without agreement of the national park administration. Our research revealed that MAP collectors harvest on their own properties in national parks, but sometimes also from other places e.g. buffer zones of national parks. We know from unofficial conversations with national park administration, that awareness concerning MAP collection exists and collection is tolerated, but not addressed. Our assumption is that national park administration does not classify MAP collection as an ecologically harmful activity. On the other hand, collectors mentioned that the national park administration prevented them from collection of MAPs in the field. We claim that such inconsistency of law interpretation has negative ecological and socio-economic implications. Moreover, "landscape 
protection" in national parks often covers habitats that require protection by use, e.g. grasslands. Therefore, we propose that such habitats could serve as a source of high quality and sustainably harvested MAPs, collection of which could be combined with the necessary use of these habitats, e.g. mowing. In any case, the law should clearly refer to a collection activity and define it. Further research is needed to recognise the problem comprehensively and look for solutions.

The Polish Plant Species Protection Act [13] appears to be convoluted in its formulation. The act establishes two categories of protection: strictly protected species and partly protected species. Additionally, the act contains a short list of the species, extracted from the partly protected category, distinguished as the only species that can be collected. This collection can take place when the permission by $R D O S$ is granted. As it is the only act directly focusing on MAPs, companies strive to follow this regulation and usually submit applications for collection permissions annually. As it was noticed before, wrong decisions can be made by $R D O S$, meaning that permissions for MAP collections were granted, even if this should not happen as regulated by law. We assume that this can be attributed to misreading of the law due to its confusing formulation and no clear delineation between the protection categories. We also assume that some agencies were not sufficiently informed about the law amendment of 2014. Nevertheless, more information is needed to explain why the agencies made these decisions.

The companies organising wild collection often mention the complexity of the procedures associated with protected MAPs and the negative impact of these procedures on their business. Mostly, long lasting procedures lead to delays in obtaining permissions (even in the middle of the season), subsequent challenges, and profit losses. Another problem mentioned by the companies is the lack of up-todate data on MAP resources, their occurrence and abundance in natural sites. Despite the economic deficits and lack of clearly defined legal framework, companies organising wild collection of MAPs are in the period of stable development. The enterprises created their own collection systems, which seem to have large degree of informality. On the one hand, these systems gain from legislative uncertainties. On the other hand, the long-term trade-offs are gradually becoming apparent: economic loses from decreasing of the plant material quality, lack of the collection stability, and compromised sustainability (primarily socio-ecological aspects).

\section{Socio-ecological aspects}

Over the years, the owners of purchase centres and collectors learned how to function in existing MAP wild collection system. The owners of the purchase centres have some degree of stability provided by annual contracts with companies. In the interviews, this group expressed a lot of satisfaction with and pride from an assigned function. Meanwhile, the situation of collectors is much more insecure. Objectively, collectors do not have any economic stability and social security. Even considering that they have a profession and a high degree of expertise that is essential in their work, their employment status has a large degree of informality and entails bearing risks. Moreover, because of lacking legislation and an informal nature of the collection, sometimes collectors are drawn into conflicts with land managers or landowners. On the other hand, collectors value the independence that is provided by informality. This allows them to treat collection as an additional source of income. Based on the analysis of our interviews it can be assumed that collectors are unaware of their importance in the supply chain; however, further research is needed to prove this assumption. It is observed that currently the collectors have no power in terms of advocating for their rights and almost no agency to shape the future of their professional occupation.

However, this group plays a crucial role in the supply chain of MAP wild collection in Poland. Currently, they are responsible for making vital decisions about: a) the exact place of collection; b) the species; c) time of day for collection; d) method of collection; e) method of transport of the collected material to home; f) drying conditions; g) storing; h) the moment of sale to a purchase centre or a company. Moreover, collectors have a large responsibility for the correct identification of the species. The decisions they make directly impact plant material quality. Nevertheless, collectors are the subject to various, very often uncomfortable, working conditions in the wilderness. An occupational hazard is a part of this profession, e.g. Lyme disease. We also observe that collectors, local people, have the best knowledge of the area, local vegetation and place of occurrence of species. They often develop new methods of plant collection or drying, which are worth of study.

\section{CONCLUSIONS}

Scattered and incoherent regulation of wild collection causes confusion, mistakes and does not allow 
collectors to act legally and safely. It needs a revision. We do not argue for the tightening of the regulation, which could increase paperwork and limit the access to MAP resources by collectors and companies. We would recommend unification of the norms regulating wild collection in one act, harmonised with the international obligations of the country and local sustainable practices. Such law should focus on MAPs (all species, not only protected ones) that are collected for commercial purposes in nature. We recommend the development of a comprehensive monitoring system, controlling any commercial collection of MAPs, with special attention to the species and locations. We consider it feasible to use modern technology for these purposes, e.g. a smartphone application or publicly accessible database. Such a system could provide reliable data about the commercial collection in the country, which in turn would ease the bureaucratic load on the businesses and public administration as well as provide benefits for the ecosystems.

We conclude that informal professional occupation of wild collectors and people who practice this activity need exceptional and urgent focus. More attention should be paid to collectors and their empowerment, so that it could radically improve the quality of wild collected plant material. The change could start from the emphasis on GACP, as an obligatory standard for all collectors. This solution could evolve from a cooperation of companies with educational institutions, e.g. universities. We think that, through getting the attention of various groups of interest involved in the system of MAP wild collection, e.g. businesses, collectors, agencies and universities, it will be possible to improve the functioning of the system. We conclude that the increase in the quality standards for the MAP material is an additional incentive to update and redefine the wild collection system in Poland.

Despite general trend to rely mainly on cultivated plant material indicated by some MAP specialists as a safer option in terms of quality, we insist that the continuation of practices and of the improvement of wild collection system is more important than ever before. It is essential for counteracting of the progressing threats of climate change and disadvantages posed by monoculture. Currently, agricultural systems are under redefinition in direction of biodiversity support and incorporation of agroecological ideas. The aim is to increase their resilience to the climate change. We conclude that the resilience of biodiverse ecosystems providing MAPs is a function of sustainable management and good collecting practices, which have a future. Moreover, besides an ecological, wild collection inherit other positive social, cultural, and most likely economic implications in and for the rural areas.

\section{ACKNOWLEDGEMENTS}

We would like to say words of thanks to all our fantastic informants who entrusted us with their knowledge and agreed to be interviewed. The research was done in frame of "PharmaHerbs" project realised in 2017-2018, founded by Ministerium für Wissenschaft, Forschung und Kunst, Baden-Württemberg, Germany.

Conflict of interest: Authors declare no conflict of interest.

\section{REFERENCES}

1. Schippmann U, Leaman $D$, Cunningham $A B$. A comparison of cultivation and wild collection of medicinal and aromatic plants under sustainability aspects. In: Bogers RJ, Craker LE, Lange D (eds.). Medicinal and Aromatic Plants. Vol $17^{\text {th }}$. Dordrecht 2006:75-95.

2. Lange D. Europe's medicinal and aromatic plants: their use, trade and conservation. Cambridge 1998.

3. European Food Safety Authority. Compendium of botanicals reported to contain naturally occurring substances of possible concern for human health when used in food and food supplements. EFSA Journal 2012; 10(5):2663. https://www.efsa. europa.eu/en/data/compendium-botanicals

4. Angielczyk M. Możliwości uprawy i wykorzystania ziół w warunkach województwa podlaskiego [Opportunities of herbs' cultivation and utilization in Podlaskie Voivodship]. WPODR w Szepietowie 2003 [in Polish].

5. Jambor J. Herbalism in Poland - present state and prospects of development. Post Fitoter 2007; $2: 78-81$

6. Kozłowski J, Adamczak A, Buchwald W, Forycka A. Zasoby roślin zielarskich w stanie naturalnym w Polsce i możliwości ich wykorzystania [Natural resources of medicinal plants in Poland and 
opportunities of their utilization]. Panacea 2008; 3(24):9-11 [in Polish].

7. Sadowski A, Kozłowska-Burdziak M. Produkcja ziół w województwie podlaskim i możliwość jej zwiększenia, w ramach projektu Urzędu Marszałkowskiego: wsparcie rozwoju zielarstwa w województwie podlaskim [Production of herbs in Podlaskie Voivodship and opportunities for its growth, in frames of the project of Marshal Office: a support of development on herbalism in Podlaskie Voivodship]. Uniwersytet w Białymstoku 2012 [in Polish].

8. Jambor J. Anbau von Arznei Pflanzen in Polen und aktuelle Forschungsarbeiten im Arznei- und Gewürzpflanzenbereich [Cultivation of medicinal plants in Poland and actual research on medicinal and culinary herbs]. Polish Herbal Commitee. Workshop. In: Julius-Kuhne-Archive 460 of the 8th Tagung Arznei- und Gewürzpflanzenforschung; 2018 Sept 10-13; Bonn 2018:135-138 [in German].

9. Research Institute of Medicinal Plants, Polish Herbal Committee. Rynek ziół w Polsce i w Unii Europejskiej [Market of medicinal plants in Poland and European Union]. In: Stan i perspektywy rozwoju upraw zielarskich oraz kierunki ich wykorzystania 2012. www.zodr.pl/download/ technologia/rynekziol.pdf, Accessed on 20 November 2017. [in Polish].

10. Majewska E. "O Marnotrawstwie i Śkąpstwie, Lasom szkodliwych..." - a współczesne dylematy dotyczące racjonalnego użytkowania leśnych surowców niedrzewnych [, ... ”- contemporary challenges on sustainable use of non-timber forest products]. Studia i Materiały CEPL Rogowo 2014; 16(38):31-39 [in Polish].

11. Mirek Z, Pięknoś-Mirkowa H, Zając A, Zając M. Flowering plants and pteridophytes of Poland. A checklist. Krytyczna lista roślin kwiatowych i paprotników Polski. Kraków, Instytut Botaniki Polskiej Akademii Nauk 2002 [in Polish].

12. Szafer W, Kulczyński S, Pawłowski B. Rośliny polskie [Polish plants]. Vol. I, II. Warszawa 1986 [in Polish].

13. Rozporządzenie Ministra Środowiska $\mathrm{z}$ dnia 9 października 2014 r. w sprawie ochrony gatunkowej roślin [Minister of Environment Regulation of 9 October 2014 on plant species protection] (Dz. U. 2014, poz. 1409) [in Polish].

14. Convention on Biological Diversity. https://www. cbd.int/. Accessed in November 2020

15. Convention on International Trade in Endangered Species of Wild Flora and Fauna. https:// www.cites.org/. Accessed in November 2020

16. Allen D, Bilz M, Leaman D.J, Miller R.M, Timoshyna A, Window J. European Red List of Medicinal Plants. Luxembourg 2014.

17. Council Directive 92/43/EEC of 21 May 1992 on the conservation of natural habitats and of wild fauna and flora. Accessed in November 2020

18. World Health Organisation. WHO guidelines on good agricultural and collection practices (GACP) for medicinal plants. Geneva, 2003. Accessed in November 2020

19. European Medicines Agency, Committee on Herbal Medicinal Products. Guideline on good agricultural and collection practice (GACP) for starting materials of herbal origin. London, 2006. Accessed in November 2020

20. Ustawa $\mathrm{z}$ dnia 16 kwietnia 2004 r. o ochronie przyrody (Dz. U. (2004), nr. 92, poz. 880) [in]: Obwieszczenie Marszałka Sejmu Rzeczypospolitej z dnia 22 listopada 2019 r. w sprawie ogłoszenia jednolitego tekstu ustawy o ochronie przyrody [Nature Protection act of 16 April 2004] (Dz. U. (2020) poz. 55) [in Polish].

21. Ustawa o lasach $\mathrm{z}$ dnia 28 września $1991 \mathrm{r}$. [Forest act of 28 September 1991] (Dz.U. (1991), nr 101 poz. 444) [in Polish].

22. Rozporządzenie Ministra Ochrony Środowiska, Zasobów Naturalnych i Leśnictwa z dnia 28 grudnia 1998 r. w sprawie szczegółowych zasad ochrony i zbioru płodów runa leśnego oraz zasad lokalizowania pasiek na obszarach leśnych [Regulation of Minister of Nature Protection, Natural Resources and Forestry of 28 December 1998 on rules of protection and collection of forest groundcover products and location of apiaries in forests] (Dz. U. (1999), nr 6, poz. 42). [in Polish]

23. Council Regulation (EC) No 834/2007 of 28 June 2007 on organic production and labelling of organic products and repealing Regulation (EEC) 
No 2092/91. This act has changed. Current consolidated version: 01/07/2013. http://data.europa. $\mathrm{eu} / \mathrm{eli} / \mathrm{reg} / 2007 / 834 / \mathrm{oj}$. Accessed in November 2020

24. Ustawa o rolnictwie ekologicznym z dnia 25 czerwca 2009 r. (Dz. U. (2009), nr 116, poz. 975) [Act on ecological agriculture of 25 June 2009]. [in Polish].

25. FairWild Foundation. FairWild Standard: Version 2.0. FairWild Foundation. Weinfelden, Switzerland 2010a http://www.fairwild.org/documents/. Accessed in November 2020

26. FairWild Foundation. FairWild Standard: Version 2.0 / Performance Indicators. FairWild Foundation, Weinfelden, Switzerland 2010b. http://www.fairwild.org/documents. Accessed in November 2020

27. Interview with the owner of " $y$ " company in Mai 2017.

28. Interview with the owner of " $z$ " company in November 2017.
29. Agricultural and Food Quality Inspection Main Inspectorate IJHARS. Liczba producentów ekologicznych w Polsce [Number of ecological producers in Poland]. https://www.gov.pl/web/ ijhars/dane-o-rolnictwie-ekologicznym. Accessed on 31 December 2018 [in Polish]

30. Interview with the owner of " $x$ " company in February 2017.

31. Magda I, Kiełczewska A, Brandt N. The "Family $500+$ " child allowance and female labour supply in Poland. IBS working paper, 2018.

32. Rozporządzenie Ministra Środowiska $\mathrm{z}$ dnia 9 października 2014 r. w sprawie ochrony gatunkowej grzybów (Dz.U. 2014 poz. 1408) [Minister of Environment Regulation of 9 October 2014 on mushroom species protection] [in Polish].

33. Rozporządzenie Ministra Środowiska z dnia 9 lipca 2004 r. w sprawie gatunków dziko występujących roślin objętych ochroną (Dz. U. (2004), nr. 168, poz. 1764) [Minister of Environment Regulation of 9 July 2004 on naturally occurring protected plants] [in Polish]. 